\title{
Education And The Corona Pandemic: Lessons LearnedExploring Teaching And Learning Needs After The Corona Pandemic: Curriculum And Teaching Methods
}

\author{
Author: Dr. KhursheedaKhatoon \\ Faculty University College Dayer, Jazan University, KSA \\ Co-author: MsSulafa Mohammed Gewi \\ Faculty University College Dayer, Jazan University, KSA
}

Article History:Received:11 January 2021; Accepted: 27 February 2021; Published online: 5 April

\begin{abstract}
The education system all over the world is been highly affected by coronavirus and Covid-10 pandemic when the lockdown was announced worldwide. In order to control and prevent the spread of the virus, the schools, colleges, and even the universities was closed. This closure of educational instititutes had bought up number of difficulties for the student, teacher, and the parents as well and inorder to overcome the situation and continue the system of education, online or distance learning policy was offered and adapted by each and everyone that were associated with the educational system. It was a challenge for the developing countries wgwre thre is lack of facilities like internet access, infrastructure, and gadgets as well. There were countries where the fee of internet was reduced, educational resources were provided by the governing bodies so as to fill the gap. There is a huge pressure on the teaching staff to adapt the online teaching mode and conduct the classes by first learning the process for themselves. Everyone had make all the efforts to learn and adapt the new way of teaching and learning and making the process smooth in the coronavirus pandemic situation.
\end{abstract}

Keywords: Education, Corona Virus, Pandemic, Learning, Teaching, Technology

\section{Introduction}

Every crisis comes with two crucial needs, including resolving emerging issues immediately and preventing it from occurring again. Coronavirus pandemic is no different from these needs as leaders of every country have to focus on both limiting this outbreak to save lives and to improve conditions of living in postCOVID-19 period. Education is one of most crucial sectors that have faced issues and changed ways to meet requirements of students. This once-in-a-century pandemic has even traveled through lives of students and policymakers in educational sector.

All across world, this pandemic has changed conditions of every day educational organizations. Hence, this essay is going to focus on lessons that human beings have learned through this pandemic regarding changing perception of education process and curriculum.

\section{Lessons from coronavirus pandemic that has given a new shape to future of education}

Including students of USA, around 1.2 billion students all over world are out of classroom right now. Due to this reason, entire world has focused on changing ways of leading life and education department is no different from this. A dramatic change has been witnessed in this sector in form of emerging process of digital teaching and learning methods. Entire system has changed regarding education to retain information. At same time, it has also been suggested by researchers that these changes are also going to influence perception of people regarding education in post corona era. However, e-learning, online classes, and digital education are not new concepts in this age of digitization and advanced technology. It is prominent that in 2019, investment in edtech internationally reached US\$18.66 billion (Iste.org, 2020). It has also been identified that market of online education was forecasted to reach an investment of $\$ 350$ billion at end of 2025 . From that aspect, it is quite natural to say that even before occurrence of corona pandemic video conferencing; virtual tutoring and language application tools were there to make education easier.

Outbreak of this pandemic has changed perception of education system of entire world along with its process of responding to COVID-19. In this period, think and learning apps are getting chances to expand business more efficiently with a bolstering capacity of inspiring and helping students and teachers simultaneously (Kohli, 2020). Unlimited video conferencing time over online platforms is helping both teacher and student to stay connected along with enhancing experience of learning of students smoothly.

Along with learning applications, school districts are also working efficiently to develop partnerships to broadcast live learning sessions for students. For example, PBS SoCal/KCET and Los Angeles Unified School 
District have developed partnerships with different television channels to provide direct lessons to students of different ages simultaneously. Virtual learning has become more prominent in this period due to help of platforms and media organizations such as BBC.

It is crucial to mention in this place that while some specialists in education sector are hoping for emerging of a hybrid model in this field, some are expecting poor experience of users due to rapid and unplanned move towards online learning (Nejm.org, 2020). For example, some experts are afraid of consequences of little preparation, insufficient bandwidth, and no training; some are highly optimistic about benefits of e-learning. Primary reason behind such a factor is that expectations of teachers to accept online education as an integral part of education system.

\section{Lessons from lockdown and educational system}

During lockdown, along with health sector education system has also faced issues regarding sustainability and providing equal chance to every student to stay in touch with education. While world's largest education chain equipped with advanced technology faced fewer issues to maintain level of education among millions of students, smaller educational players faced a larger number of issues (Nytimes.com, 2020) ). For example, it has taught four aspects of education system along with its strength and weakness. These aspects include classrooms, equity, technology, classrooms, and beyond technology.

At same time, this pandemic has come with issues such as challenges regarding improving distance learning after developing and maintaining it. Parents and teachers were not prepared for home and distance learning; due to this reason, interrupted learning and stress for teachers increased simultaneously (Weforum.org, 2020). It has also been identified that some teachers have shown their concern towards pay gap. Homeschooling left teachers with frustration for this type of equity gap in US.

Quality education has been prioritized during crisis of COVID-19 after focusing on each challenge and opportunity in education system. Major reason behind this factor is occurrence of inequities in this sector. This period has also shown inequity among students regarding having sufficient internet connections and devices. Millions of students have completely cut off from education due to lack of sufficient equipment. This period has also shown difference between students from privileged and underprivileged backgrounds in US within having computer system to stay connected to teachers.

In such a situation, some educational organizations have faced issues with maintaining equity in many forms. For example, they needed to make most suitable decisions regarding that is also difficult. It was quite tough for them to provide learning sessions regarding curriculum for months to all students without teaching them remotely. However, these organizations also face issues regarding providing a chance to underprivileged students to complete their curriculum activities.

It has also been seen that this lockdown and pandemic of corona have shown difference between two parts of students, along with difference and inequity between privilege and power of parents of students (Nejm.org, 2020). At same time, lack of digital education among parents has also created issues regarding helping students during switching to online learning.

Along with issues of equity among parents and students, inequity has also been identified among payments to teachers. At same time, this uncertain period has also shown importance of classrooms. It was not easy for every organization to move towards online system of learning, whether it is higher education or schooling system. Due to this reason, online classrooms have faced both pitfalls and promises to students regarding integrated and excellent experience regarding education. It is also crucial to mention in this place that experience of students goes beyond use of technology and knowledge of teachers and process of coping with this process. For example, it is also crucial for teachers to ensure proper learning and teaching method along with growth and development of students regarding specific topics (Qz.com, 2020). It is quite tough for teachers from the other side of screen to say whether students are listening to them properly and learning the exact thing they want to say.

\section{Aspects of moving forward towards new curriculum and teaching method}

This pandemic has shown importance of flexibility and acceptance of human beings to survive any type of situation whether it comes to health or education. Online transition has come into force suddenly and it has introduced 'new normal' in places of 'common normal.' Now, people are growing new habits to stay strong in this volatile world and fighting invisible enemy. At same time, this period has shown essential approach of disseminating knowledge. This time has clearly denied importance of some asserts and it is also going to provide importance to some imperatives (Shah et al. 2020). It can be said that traditional system of education is losing relevance more than ever and it is time to unfold potentiality of newer system of education.

In the time before COVID-19 pandemic, this system used to follow standardization and memorization on basis of IQ that was built based on model of industrial revolution. However, it is time to focus on long-term economic value and providing proper education to students that can help them to stand strong against machines 
(Weforum.org, 2020). In this age, curriculum and system of education also need to focus on quality, equity, and access to education.

Global education crisis has emerged in this period of time, and due to this reason, it is essential for governments and educational institutions to focus on factors such as improving education system. For example, it is crucial for education professionals to ensure practice and preparation regarding completing study online. In order to do so, it is essential to ensure digital equity, taking time to plan properly, and providing clear expectations to parents and staff.

\section{Conclusion}

In conclusion, it is crucial to mention that in this war between coronavirus and entire world students of USA are also suffering to an extent. While privileged students are getting proper chance to continue their study with help of technology underprivileged students are going through uncertainties. However, this essay has also identified that it was quite tough for students, teachers, and parents to cope up with such an environment overnight. It has also been seen that even after facing problems regarding lack of training and preparation regarding online and digital education both teachers and students show their concern regarding proper study.

At same time, this pandemic situation has shown inequity among teachers, students, and parents along with importance of online classes and applications for learning. This period has also come with changes from assertive to imperative aspects of education and curriculum.

\section{Bibliography}

1. Abu-Qdais, H., Al-Ghazo, M., \& Al-Ghazo, E. (2020). Statistical analysis and characteristics of hospital medical waste under novel coronavirus outbreak.Global Journal of Environmental Science and Management, 6(4), 1-10. doi:http://dx.doi.org/10.22034/gjesm.2020.04.0

2. Iste.org (2020) 10 strategies for online learning during a coronavirus outbreak, Retrieved on $15^{\text {th }}$ June 2020 from: https://www.iste.org/explore/learning-during-covid-19/10-strategies-online-learning-duringcoronavirus-outbreak

3. Kohli, A. (2020). Can imaging impact the coronavirus pandemic? The Indian Journal of Radiology and Imaging, 30(1), 1-3. doi:http://dx.doi.org/10.4103/ijri.IJRI_180_20

4. Nejm.org (2020) History in a Crisis- Lessons for Covid-19, Retrieved on $15^{\text {th }}$ June 2020 from: https://www.nejm.org/doi/full/10.1056/NEJMp2004361

5. Nejm.org (2020) Responding to Covid-19 - A Once-in-a-Century Pandemic?, Retrieved on $15^{\text {th }}$ June 2020 from: https://www.nejm.org/doi/full/10.1056/NEJMp2003762

6. Nytimes.com (2020) Coronavirus Resources: Teaching, Learning and Thinking Critically, Retrieved on $15^{\text {th }}$ June 2020 from: https://www.nytimes.com/2020/03/11/learning/coronavirus-resources-teachinglearning-and-thinking-critically.html

7. Qz.com (2020) The coronavirus pandemic is reshaping education, Retrieved on $15^{\text {th }}$ June 2020 from: https://qz.com/1826369/how-coronavirus-is-changing-education/

8. Shah, K., Dhwani, K., Hema, M., Birinder, M., Desai, K., \& Patel, R. S. (2020). Focus on mental health during the coronavirus (COVID-19) pandemic: Applying learnings from the past outbreaks. Cureus, 12(3) doi:http://dx.doi.org/10.7759/cureus.7405

9. Shah, K., Gaurav, C., Dhwani, K., Amindeep, L., \& Patel, R. S. (2020). How essential is to focus on physician's health and burnout in coronavirus (COVID-19) pandemic? Cureus, 12(4) doi:http://dx.doi.org/10.7759/cureus.7538

10. Weforum.org (2020) The COVID-19 pandemic has changed education forever. This is how, Retrieved on $15^{\text {th }}$ June 2020 from: https://www.weforum.org/agenda/2020/04/coronavirus-education-globalcovid19-online-digital-learning/

11. Weforum.org (2020) What lessons from the coronavirus pandemic will shape the future of education?, Retrieved on $15^{\text {th }}$ June 2020 from: https://www.weforum.org/agenda/2020/05/covid19-lockdown-futureeducation/ 